\title{
Improving Fisheries Estimates by
Including Women's Catch in the Central \\ Improving Fisheries Estimates by
Including Women's Catch in the Central Philippines
}

\section{DANIKA KLEIBER}

Corresponding Author: d.kleiber@fisheries.ubc.ca

\section{LEILA M. HARRIS}

\section{AMANDA C.J. VINCENT}

University of British Columbia, 2014

Final version: Kleiber, D., L. Harris, A. Vincent (2014) Improving Fisheries Estimates by Including Women's

Catch in the Central Philippines. Canadian Journal of Fisheries and Aquatic Sciences 71 (5): 656-664. DOI: 10.1139/cjfas-2013-0177

Citations of this work should use the final version as noted above 


\section{Table of Contents}

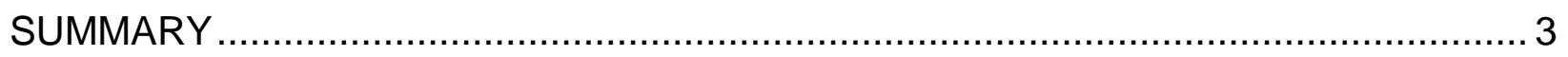

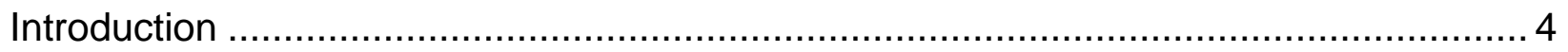

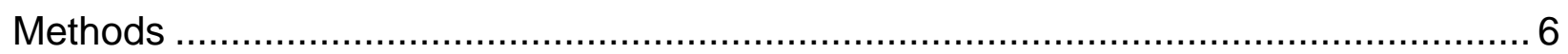

Study Area

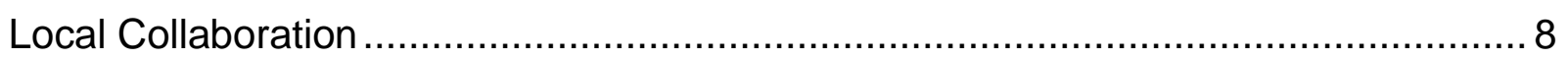

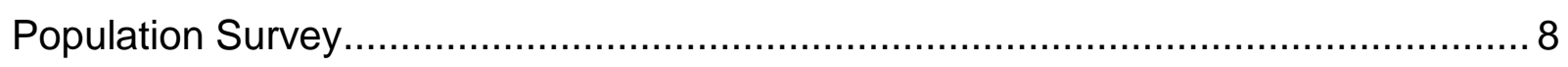

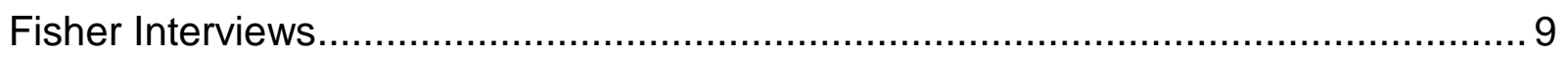

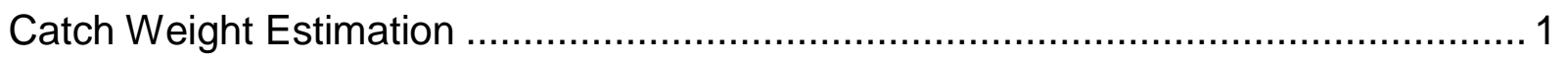

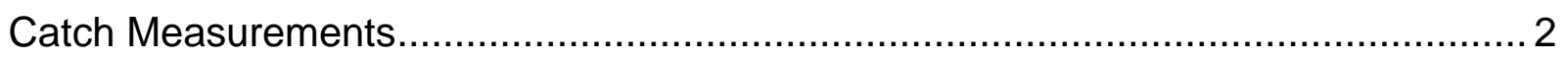

Statistical Analysis …………………………………………………...

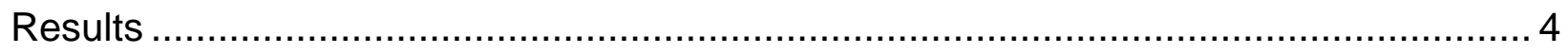

Proportion of Respondents in Different Fishing Activities ..................................... 4

Who Fishes?

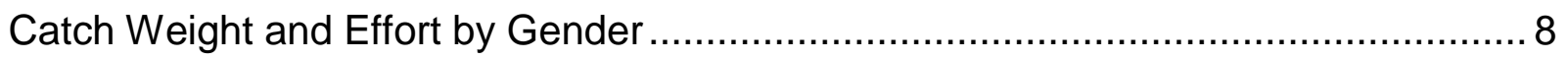

Animals Targeted by Fishing Methods............................................................. 11

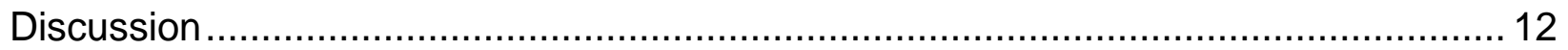

Gender and the Quantification of Small-Scale Fisheries ...................................... 12

Gender and Ecosystem-Based Management ...................................................... 14

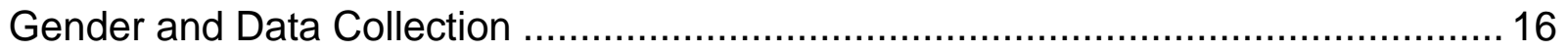

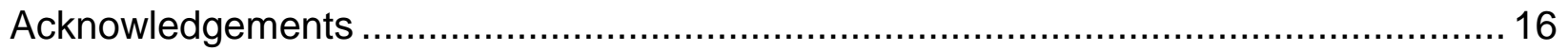

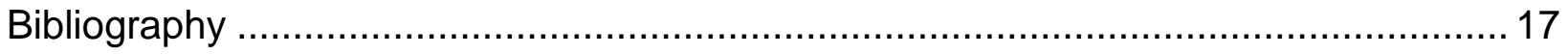




\section{SUMMARY}

Small-scale fisheries catch and effort estimates are often built on incomplete data because they overlook the fishing of minority or marginalized groups. Women do participate in small-scale fisheries, and often in ways distinct from men's fishing. Hence, the inclusion of women's fishing is necessary to understanding the diversity and totality of human fishing efforts. This case study examines how the inclusion of women's fishing alters the enumeration of fishers, and estimations of catch weight, fishing effort, and targeted organisms in twelve communities in the Central Philippines. Women were $42 \%$ of all fishers, and contributed approximately one quarter of the fishing effort and catch weight. Narrower definitions of fishing that excluded gleaning (gathering of benthic macro invertebrates in intertidal areas) and part-time fishing masked the participation and contribution of most women fishers. In this case study it is clear that overlooking women, part-time, or gleaning fishers led to the underestimation of fishing effort and catch weight. Overlooking gleaning had also led to underestimation of shells and other benthic macro invertebrates in fishing catches.

Keywords: ecosystem-based management, gender, fishing effort, small-scale fisheries, the Philippines 


\section{INTRODUCTION}

Women's participation in small-scale fisheries has been described but rarely quantified (Quinn and Davis 1997). Descriptions of women's fishing challenge the notion that small-scale fishing is exclusive to men (Weeratunge et al. 2010), but the lack of quantification of women's fishing, and the fishing of other minority or marginalized groups, has several consequences for the understanding and management of smallscale fisheries. First, it accentuates the data scarcity in small-scale fisheries that results in the local and global underestimation of fishing effort and catch (Zeller et al. 2007a). Second, it creates an incomplete understanding of the diversity of and interactions between small-scale fishing strategies, which in turn hinders ecosystem-based management approaches. Finally, it underestimates women's contribution to fisheries (Mills et al. 2011), which leads women to be invisible in the management of small-scale fisheries and marine resources.

Small-scale fisheries may account for over half of the catch of developing country fisheries (FAO and WorldFish Centre 2008), and characterize up to $90 \%$ of the world's fishers (Béné et al. 2007). And yet small-scale fisheries continue to be unaccounted for in national fisheries statistics, resulting in severe underestimations of catch weight and fishing effort (Zeller et al. 2007b, Metuzals et al. 2010). The quantification and characterization of small-scale fisheries using traditional fisheries assessment methods are hindered by 1) a lack of research capacity (McCluskey and Lewison 2008), and 2) the diversity of fishing strategies and ecosystem complexity (Andrew et al. 2007). To overcome deficits in data and research capacity, techniques have been developed to quantify and assess small-scale fisheries using fisher knowledge (Neis et al. 1999, 
O'Donnell et al. 2010). To account for fisheries and ecosystem complexity ecosystembased approaches to fisheries is being developed (Pomeroy et al. 2010).

Ecosystem-based management needs to address complex systems by focusing on the numerous ecological and social interactions that occur in small-scale fisheries (McLeod et al. 2005, Pomeroy et al. 2010). To identify ecological and social interactions it is first necessary to define the species, habitats, and fishing strategies that will be included in management (Pomeroy et al. 2010). Gender may be a key consideration for identifying fishing strategies as women and men often have distinct and interacting roles in smallscale fisheries (Chapman 1987, Siar 2003, Magalhães et al. 2007, Medard 2012), with women and men often targeting different marine life and habitats (Bliege Bird 2007, Hauzer et al. 2013). Hence, if women and other minority or marginalized groups are not included, there is a great potential to miss certain fishing strategies, and subsequently key social and ecological interactions.

Ecosystem-based management emphasizes humans as a part of, rather than apart from, the ecosystem and embraces the inclusion of stakeholders in the decision-making process (McLeod et al. 2005). The challenge then becomes determining which humans and human activities are counted and subsequently whose voices and management priorities are included in resource management decision-making. There is a widespread underrepresentation of women in natural resource labour statistics (United Nations 2006), and the effect of this invisibility on management and decision-making has been widely examined in the gender and development literature (Upadhyay 2005, Vernooy 2006, Resurreccion and Elmhirst 2008, Agarwal 2009), and more specifically in the gender and fisheries literature (Walker and Robinson 2009, Weeratunge et al. 2010). In 
the gender and fisheries literature there is often an emphasis on women's labour in catch processing and marketing (Overå 1993, Tindall and Holvoet 2008). Including women's labour in the fisheries value chain fits within the aim of ecosystem-based management to integrate ecological and socio-economic interactions (Allison and Ellis 2001, Béné et al. 2009, Weeratunge et al. 2010), but it still misses the quantification and characterization of women fishers and their ecological interactions in the marine ecosystem.

This research examines how the exclusion of women and other overlooked categories of fishers change the quantitative assessment of small-scale fisheries at the community scale using a case study of small-scale fisheries in the Central Philippines. Women are known to participate in the many small-scale fisheries found in the Philippines, but quantification is rare (Siar 2003; Illo and Polo 1990). First the number of women and men fishers was estimated and their fishing methods were examined. The fishing effort and catch weight were then quantified to compare the total contribution of women and men, and part-time and full-time fishers. Finally the types of animals targeted by different fishing methods were examined to characterize fishing catch. The results of this study have direct implications for management as they highlight the contribution of overlooked fishers and fisheries, as well as demonstrate the greater diversity of marine life targeted by human fishing activity.

\section{METHODS}

To characterize small-scale fisheries in the Central Philippines population surveys, fisher interviews, and direct measures of catch were conducted to gather to quantitative 
and qualitative data on fishers and their fishing methods, catch weight, fishing effort, and target species.

\section{Study Area}

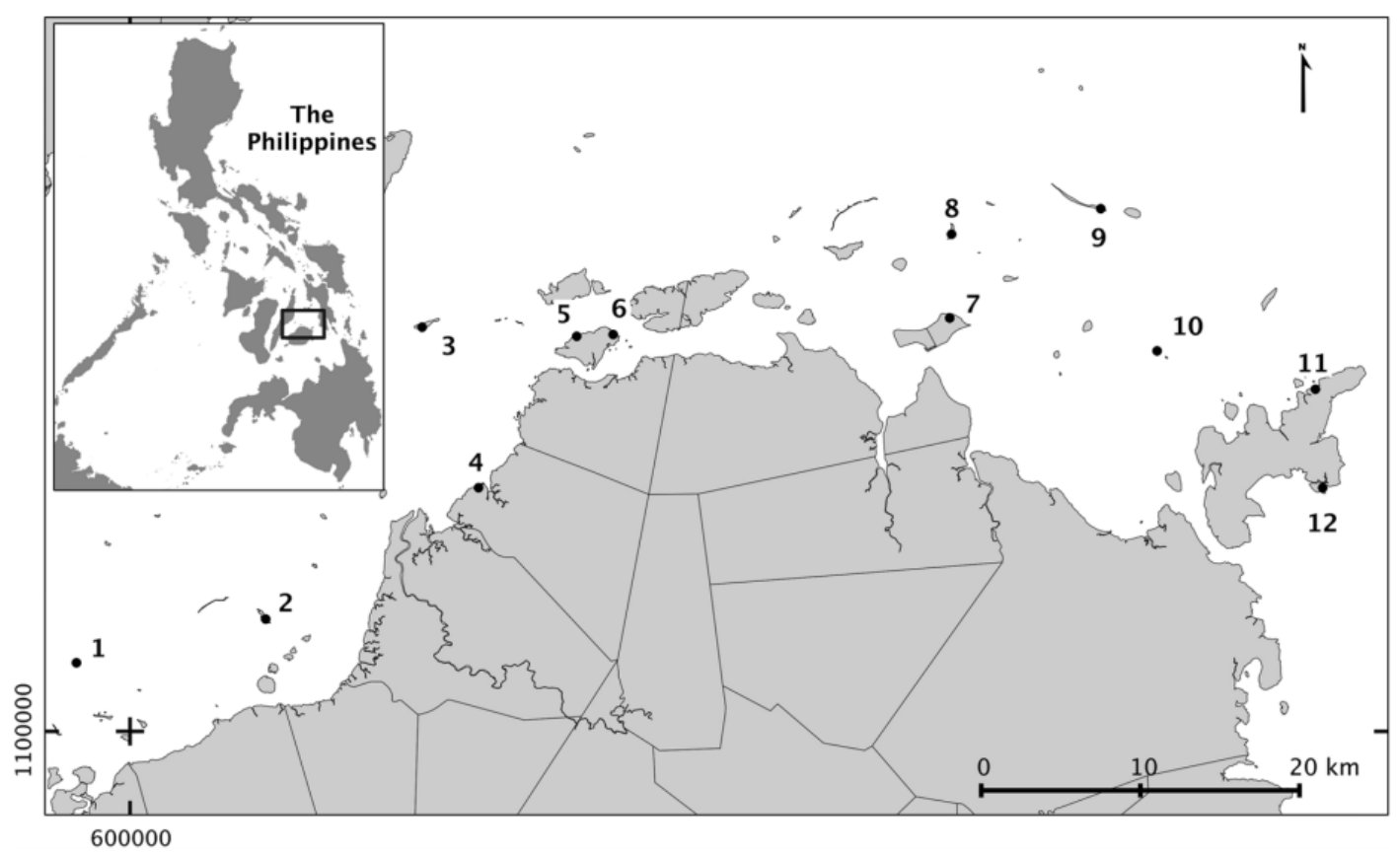

Figure 1. Study communities in the Central Philippines. The study sites are as follows: 1) Bilangbilangan West, 2) Batasan, 3) Pandanon, 4) Asinan, 5) Jandayan Norte, 6) Handumon, 7) Pinamgo, 8) Cataban, 9) Bilangbilangan East, 10) Butan, 11) Saguise, 12) Aguining.

Our study took place in the Danajon Bank region of the Central Philippines (Figure 1). Communities in this region are largely ethnically homogeneous, and while there is variation in access to material wealth, there are overall high levels of poverty (Guieb 2008). The Philippines has one of the highest per capita fish consumption rates in the world (Yap 1999), and in the Danajon Bank marine resources are caught using smallscale fishing practices. The Philippines is a hotspot of marine biodiversity, but the marine ecosystem is under great fishing pressure (Carpenter and Springer 2005; 
Christie et al. 2006). Destructive and over-efficient fishing methods such as dynamite fishing, cyanide, and illegal trawling occur in the Danajon Bank. Marine management in the Philippines is decentralized, with responsibilities falling at the community and municipal levels of governance. Ecosystem-based management is used to account for the myriad of fishing methods used and species caught (Armada et al. 2009). Certain management measures such as boat registration and gear restrictions are done at the municipal level. Other management measures such as Marine Protected Areas (MPAs) are mostly managed at the community level with co-management assistance of local environmental NGOs collaborating with international partners (e.g. Christie et al. 2006).

This case study included twelve communities, representing six municipalities in the north of Bohol province. Half of the study communities were on small islands or cayes, five were found on much larger terrestrial islands, and one was on the mainland of the island of Bohol (Figure 1).

\section{Local Collaboration}

This research was done in collaboration with a local conservation NGO, Project Seahorse Foundation for Marine Conservation (PSF), which has worked with Danajon Bank communities since 1996. PSF supported our research by providing connections to the local community leaders, facilitating research permits, and providing expert input.

\section{Population Survey}

The population census data was an unreliable source of total population size or fisher population size. Many of the people counted in the census were not currently residing in the community, and the identification of fishers was infrequent and unreliable. Only 
three communities recorded information on occupation, and it was unclear if the definitions used to identify fishers in the census matched the definition used in this study, which included anyone that had gleaned or used any other fishing method during the last year.

The census data for each community was stratified by gender. Women and men (here defined as anyone over the age of 16) were randomly selected using the assignment of a random number to each respondent, which were then selected in a descending order.

Randomly selected respondents were categorized as either 1) non-residents, 2) resident fishers, or 3) resident non-fishers by either asking them directly or in cases where they were not available, asking a key informant (most often a Barangay health worker or community leader). Because gleaning is not always considered a form of fishing, respondents or key informants were asked if they had fished (pangisda) or gleaned (panginhas).

\section{Fisher Interviews}

To characterize small-scale fishing practices by methods used, fishing effort, and catch weight, women $(n=297)$ and men $(n=293)$ were interviewed about their individual fishing practices (Table 1). The interview respondents were volunteers from the randomly selected survey respondents who had fished in the last year. In cases where a respondent could not be found, a family member or neighbour was substituted. 
Table 1. Sample size for data collection by method in each community with estimates of residents and fisher populations.

\begin{tabular}{|c|c|c|c|c|c|c|c|c|c|c|c|}
\hline \multirow[t]{2}{*}{ Site } & \multicolumn{2}{|c|}{ Survey } & \multicolumn{2}{|c|}{$\begin{array}{l}\text { Individual } \\
\text { Interview }\end{array}$} & \multirow{2}{*}{$\begin{array}{r}\begin{array}{c}\text { Catch } \\
\text { measure }\end{array} \\
\text { all }\end{array}$} & \multicolumn{2}{|c|}{$\begin{array}{l}\text { Census } \\
\text { population size } \\
\mathrm{N}_{\text {census }}\end{array}$} & \multicolumn{2}{|c|}{$\begin{array}{l}\text { Estimated resident } \\
\text { population size (SD) } \\
\qquad N_{\text {residents }}\end{array}$} & \multicolumn{2}{|c|}{$\begin{array}{c}\text { Estimated fisher } \\
\text { population size (SD) } \\
\qquad \mathrm{N}_{\text {fishers }}\end{array}$} \\
\hline & $w$ & $m$ & $w$ & $m$ & & $w$ & $m$ & $w$ & $m$ & $w$ & $m$ \\
\hline 1 & 65 & 77 & 25 & 24 & 27 & 244 & 245 & 131 (8) & $184(7)$ & $116(8)$ & $162(7)$ \\
\hline 2 & 109 & 93 & 25 & 25 & 25 & 403 & 410 & 199 (10) & 273 (9) & 107 (9) & $234(10)$ \\
\hline 3 & 60 & 47 & 25 & 25 & 20 & 753 & 779 & $414(14)$ & 547 (13) & $326(13)$ & $480(14)$ \\
\hline 4 & 60 & 45 & 24 & 25 & 17 & 273 & 318 & 200 (7) & 247 (7) & 141 (8) & $184(9)$ \\
\hline 5 & 55 & 73 & 25 & 25 & 24 & 294 & 272 & $176(8)$ & $250(5)$ & 128 (9) & 212 (7) \\
\hline 6 & 57 & 84 & 24 & 22 & 22 & 316 & 385 & $216(8)$ & 316 (7) & $166(9)$ & $289(8)$ \\
\hline 7 & 33 & 35 & 25 & 25 & 21 & 773 & 799 & $446(14)$ & $616(12)$ & 399 (14) & $480(14)$ \\
\hline 8 & 77 & 81 & 24 & 25 & 23 & 388 & 435 & 267 (9) & 311 (9) & 177 (9) & $280(10)$ \\
\hline 9 & 49 & 44 & 25 & 25 & 22 & 254 & 280 & 218 (5) & $236(6)$ & 181 (7) & $229(6)$ \\
\hline 10 & 67 & 82 & 25 & 25 & 14 & 233 & 248 & $133(8)$ & 191 (7) & 111 (8) & $163(8)$ \\
\hline 11 & 62 & 60 & 25 & 24 & 20 & 252 & 252 & $163(7)$ & $206(6)$ & $126(8)$ & $105(8)$ \\
\hline 12 & 58 & 34 & 25 & 24 & 19 & 750 & 754 & 362 (14) & 422 (14) & 349 (14) & 355 (14) \\
\hline TOTAL & 752 & 755 & 297 & 293 & 254 & 4933 & 5177 & 2925 (35) & 3799 (32) & 2329 (35) & 3173 (35) \\
\hline
\end{tabular}

$w=$ women, $m=$ men 
Fishers were asked to describe their fishing from the previous year including the fishing methods they used, and for each method the catch weight of a typical catch, the typical duration (in hours) of a single fishing trip, the frequency of fishing trips per week, and the number of fishers involved. CPUE was calculated as $\mathrm{kg} \cdot$ fisher hour ${ }^{-1}$. In cases where more than one fisher participated the catch was divided by the number of participants. This CPUE measure focuses on human effort, rather than an index of abundance. The smaller unit of hours rather than days was used to describe effort to capture variations that might be more relevant for the inclusion of part-time and occasional fishers, as well as for non-boat fishing methods, such as gleaning.

All interviews were conducted by one of four local research assistants in the Cebuano language and later translated to English by the interviewer. In other case studies of small-scale fisheries women respondents reported a preference for talking to someone of their own gender (Adeokun and Adereti 2003), so in this study the gender of the research assistant was matched to the gender of the respondent. In 14 cases interviews were removed due to insufficient or unreliable data.

\section{Catch Weight Estimation}

Two different methods were used to estimate catch weight from interviews. When reporting fish catch fishers typically used kilograms, but when reporting invertebrate 
catch fishers were more likely to estimate catch size by the number of Caltex or one-liter containers they were able to fill. A conversion factor of Caltex to kilograms was created by taking the mean weight the contents of mixed and single species shells of 229 Caltex containers $(1.012 \mathrm{~kg} \pm 0.012 \mathrm{SE})$. For the purposes of this analysis the total weight of the animals is included, so in the case of gastropods and bivalves this included the weight of their shell. If examining catch contribution to subsistence or food security it would be necessary to account for the difference in edible yield of shell species and fish or cephalopods by using a measurement such as edible weight or kilocalories (e.g. Bliege Bird 2007). However in this study, animals were caught for commercial as well as subsistence purposes, and in some cases it was the shell that was of value as material for shell crafts, which are sold to tourists. To account for the economic and subsistence catch, weight was measured in total kilograms removed from the ocean as was done in other studies of multi-species reef fisheries (Matthews 2002).

\section{Catch Measurements}

To examine what types of marine life were targeted by different fishing methods a snap shot of fishing catch was taken by directly measuring the catch of 254 fishing trips, 160 of which were gleaning trips. Fishing catches were found opportunistically during the five to seven days of data collection in each community, typically by asking interview respondents if they would be willing to let us measure the catch of their next fishing trip. In other cases fishers returning with their catch were opportunistically approached at many points along the seashore to sample both subsistence and commercial catch. For each catch the fishing method used and the weight of each animal and their species category (shell, sea cucumber, urchin, crab, shrimp, octopus, cuttlefish, squid, or fish) 
was noted.

\section{Statistical Analysis}

In this study overall estimates from all twelve communities are presented. Total and fishing population estimates of women and men in each community were calculated using a multinomial bootstrap method (Chao et al. 2008) —-the bootstrap function in the R statistical package 'vegetarian' (R Development Core Team 2011, Charney and Record 2013). A data matrix for each gender was created with the counts of each category (non-resident, resident fisher, resident non-fisher) and total population size from the census as columns, and each community as a row. Proportions of each category were formed in a multinomial distribution, which was used to create a community-specific simulated population. One thousand iterations of the simulated population were used to generate a distribution of values for each category (Table 1).

Mean and standard error calculations for proportional measures of methods used and effort per week categories were weighted to account for the disproportional stratified sampling design (Gelman and Hill 2009).

To calculate the mean weekly individual catch weight, fishing effort, and CPUE by gender and by fishing method and fishing effort categories a non-parametric bootstrap analysis was used to account for the disproportional stratified sampling. First a simulated population the same size as the sample $(n=590)$ was created and populated it with the 24 sub-populations (women and men from twelve communities) in proportions that matched their representation in the total population. For each occurrence of one sub-population in the simulated population, a single random sample of the value being analyzed (e.g. $\mathrm{kg}^{\bullet}$ week $^{-1}$ ) from the corresponding sub-population was taken 
(replacement allowed). Finally the mean of the simulated population of women and men was calculated, and 1000 iterations were used to create a distribution of values. The total estimated weekly fishing effort and catch size was also estimated by taking the sum of all mean values of each simulated sub-population multiplied by the estimated sub-population size, again with 1000 iterations.

Finally proportional distribution of animal types by fishing method was estimated by taking the average weight of each animal type within each fishing method. To compare the observed results with the community perception of gender and fisheries, respondents were asked who in the community is responsible for gleaning and fishing.

\section{RESULTS}

\section{Proportion of Respondents in Different Fishing Activities}

For the purposes of this study all fishing methods have been placed into five broad categories (Table 2). Men and women participated in all five categories of fishing methods, but in different proportions. The biggest difference was between gleaning and all other forms of fishing. Almost all women interviewed participated in gleaning, whereas just over half of men gleaned (Figure 2a). Men's participation in gleaning differed as their gleaning was more often in addition to (and sometimes explained as secondary to) other forms of fishing. In all other forms of fishing men participated in higher proportions than women, and women's participation was almost exclusively in the company of a male relative, most often her husband. Of all the non-gleaning fishing methods, women's participation was highest in net fishing. 
Table 2. Description of fishing methods used.

\begin{tabular}{|c|c|c|}
\hline $\begin{array}{l}\text { Fishing } \\
\text { method }\end{array}$ & Cebuano terms* & Description \\
\hline Glean & $\begin{array}{l}\text { kaling kaling } \\
\text { kay kay, } \\
\text { kinhas } \\
\text { magmata } \\
\text { manan-aw } \\
\text { mangasag } \\
\text { mangguna } \\
\text { manginhas } \\
\text { panginhas } \\
\text { panabutangan } \\
\text { sibut } \\
\text { sundang }\end{array}$ & $\begin{array}{l}\text { This is done is done by walking in intertidal areas, and } \\
\text { collecting marine animals. Habitats can include rocky intertidal, } \\
\text { reef tops, mangroves, and seagrass beds. The habitat often } \\
\text { overlaps with shallow diving habitat, but at different tides. } \\
\text { Gleaners often use their hands and collect their catch in a } \\
\text { bucket, but they may also use a knife or machete to pry or } \\
\text { hack animals off rocks and coral, or they may use a long rod, a } \\
\text { spear, or a scratching devise known as kay kay, which is } \\
\text { illegal. Scoop nets are also occasionally used. As with diving, } \\
\text { gleaning is done at night with a lantern or flashlight. While very } \\
\text { common for gleaners to use nearby habitat, they will also travel } \\
\text { to other gleaning areas by boat. }\end{array}$ \\
\hline Net & $\begin{array}{l}\text { baling } \\
\text { bunsod } \\
\text { likum } \\
\text { manapyaw } \\
\text { pamo } \\
\text { pamukot } \\
\text { pamunsod } \\
\text { pangdumbol } \\
\text { panimilya, } \\
\text { pukot }\end{array}$ & $\begin{array}{l}\text { Nets of various descriptions are used and may be on } \\
\text { permanent corral structures, set up as passive drift nets, or } \\
\text { actively dragged. Fishers will often use methods to drive fish } \\
\text { into the nets either by swimming towards them in a coordinated } \\
\text { fashion, or using a large wooden pole that is splashed into the } \\
\text { water. Some types of nets such as bottom trawlers or double } \\
\text { and triple nets are illegal. There are also limitations of mesh } \\
\text { size. }\end{array}$ \\
\hline Hook & $\begin{array}{l}\text { bira bira } \\
\text { kitang } \\
\text { mamasol } \\
\text { palangre } \\
\text { pamasol } \\
\text { pasol } \\
\text { vlang vlang } \\
\text { undack }\end{array}$ & $\begin{array}{l}\text { Usually done from boats but can also be done from the } \\
\text { shoreline. A variety of hooks and lures are used. Many times a } \\
\text { single hook is used but there are also two varieties of multi- } \\
\text { hook and line used. }\end{array}$ \\
\hline Dive & $\begin{array}{l}\text { buso } \\
\text { pamana } \\
\text { pamang } \\
\text { panagabii } \\
\text { panarap, } \\
\text { panassa } \\
\text { panawm } \\
\text { pangispat }\end{array}$ & $\begin{array}{l}\text { Free diving is done during the day, but also during the night, } \\
\text { either with a lantern on the prow of the boat, or increasingly } \\
\text { commonly with a waterproof flashlight attached to the head. } \\
\text { Fishers may use their hands, but also use spears, rods, or } \\
\text { scoop nets. Divers may go directly from shore, or may take a } \\
\text { boat and go further afield. The diving category also includes } \\
\text { divers that use compressors, which provide an air supply that } \\
\text { allows divers to dive deeper and longer. This method is illegal } \\
\text { in many locations around the Danajon Bank. In some cases } \\
\text { respondents were specifically targeting species for the } \\
\text { aquarium trade. }\end{array}$ \\
\hline Trap & $\begin{array}{l}\text { bubo } \\
\text { pamanggal } \\
\text { pamubo } \\
\text { panapya } \\
\text { panggal } \\
\text { sapyaw }\end{array}$ & $\begin{array}{l}\text { Traps of various shapes and sizes are used, made either out of } \\
\text { bamboo or plastic mesh. }\end{array}$ \\
\hline
\end{tabular}

* Cebuano words given by respondents to describe fishing methods. They are often synonyms, but may also refer to diversity within the fishing categories. 
A) Fishing Method Categories

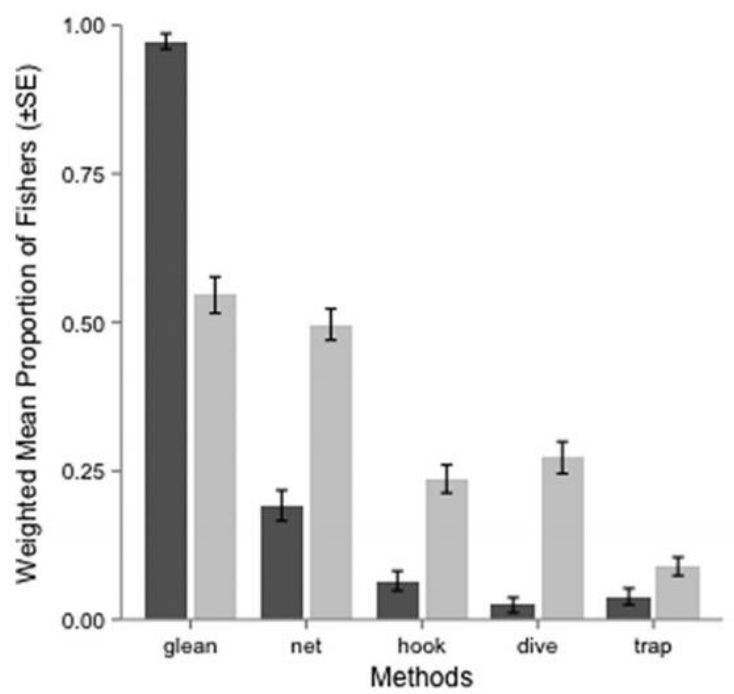

B) Fishing Effort Categories

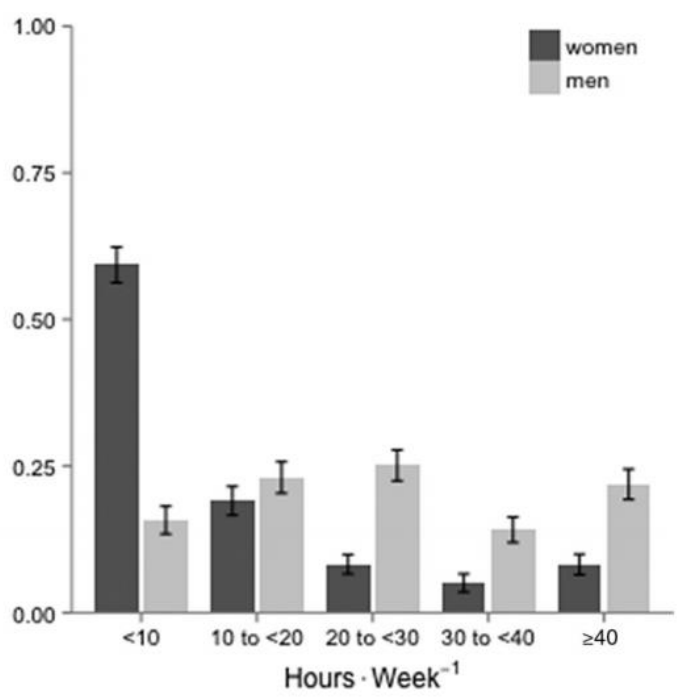

Figure 2. The proportional participation of women and men fishers by A) fishing method (each bar represents the proportion of women or men that participated in each fishing method, but categories of fishing are not mutually exclusive because participants often employ more than one form of fishing proportions within each gender do not add to 1) and B) weekly fishing effort (categories are mutually exclusive).

Respondent perception of fishing responsibilities also found a gender difference in fishing methods used. Most women $(98 \%, n=295)$ and all men $(100 \%, n=285)$ held the opinion that men were primarily responsible for non-gleaning fishing. On the other hand, gleaning was perceived to be either equally done by women and men ( $57 \%$ and $45 \%$ of women and men respondents respectively), or primarily the responsibility of women ( $31 \%$ and $28 \%$ of women and men respondents respectively). 


\section{Who Fishes?}

Women accounted for $42 \%$ of all fishers that had fished (including gleaning) in the last year. There were an estimated total of $2329(\mathrm{SD}=35)$ women fishers and $3173(\mathrm{SD}=35)$ men fishers in the twelve communities sampled (Table 1). A mean of $80 \%$ of women and $84 \%$ of men fished in these communities, but in all communities there were more men than women, mostly due to a higher occurrence of female emigration (Table 3).

Table 3. Proportion of resident fishers and population sex ratio

\begin{tabular}{|c|c|c|c|}
\hline \multirow[t]{2}{*}{ Site } & \multicolumn{2}{|c|}{$\begin{array}{l}\text { Proportion of resident } \\
\text { population that fishes } \\
\mathrm{N}_{\text {fishers }}\end{array}$} & $\begin{array}{l}\text { Resident sex } \\
\text { ratio } \\
\mathrm{N}_{\text {residents } w} \\
\mathrm{~N}_{\text {residents } m} \\
\text { (SD) }\end{array}$ \\
\hline & $w$ & $m$ & all \\
\hline 1 & $0.89(0.03)$ & $0.88(0.02)$ & $0.71(0.05)$ \\
\hline 2 & $0.54(0.04)$ & $0.86(0.02)$ & $0.73(0.05)$ \\
\hline 3 & $0.79(0.02)$ & $0.88(0.01)$ & $0.76(0.03)$ \\
\hline 4 & $0.70(0.03)$ & $0.74(0.03)$ & $0.81(0.04)$ \\
\hline 5 & $0.73(0.03)$ & $0.85(0.02)$ & $0.71(0.04)$ \\
\hline 6 & $0.77(0.03)$ & $0.91(0.02)$ & $0.68(0.03)$ \\
\hline 7 & $0.89(0.01)$ & $0.78(0.02)$ & $0.72(0.03)$ \\
\hline 8 & $0.66(0.03)$ & $0.90(0.02)$ & $0.86(0.04)$ \\
\hline 9 & $0.83(0.03)$ & $0.97(0.01)$ & $0.93(0.03)$ \\
\hline 10 & $0.84(0.03)$ & $0.86(0.02)$ & $0.70(0.05)$ \\
\hline 11 & $0.77(0.03)$ & $0.51(0.03)$ & $0.79(0.04)$ \\
\hline 12 & $0.96(0.01)$ & $0.84(0.02)$ & $0.86(0.04)$ \\
\hline MEAN & $0.80(0.01)$ & $0.84(0.01)$ & $0.77(0.01)$ \\
\hline
\end{tabular}

Using different definitions of fishing changed the estimated number of fishers, and the proportion of women fishers. The cultural definition of fishing did not include gleaning 
and eliminated $70 \%$ of women and $10 \%$ of men respondents with the result that women represented only $20 \%$ of fishers. The livelihood definition of fishing only included respondents that identified fishing (including gleaning) as their primary livelihood, and eliminated $76 \%$ of women and $10 \%$ of men, which resulted in women representing $16 \%$ of fishers.

\section{Catch Weight and Effort by Gender}

Women were responsible for catching $26 \%$ of the total estimated weekly catch weight $(\mathrm{kg})$, and $23 \%$ of the weekly fishing effort $(\mathrm{hr})$. Women's mean $\mathrm{kg}^{\bullet}$ week $^{-1}$ and $\mathrm{hr}^{\bullet}$ week $^{-1}$ were less than half that of men's but their average CPUE was slightly higher (Table 4). Most women (78\%) fished less than 20 hours a week, while most men $(61 \%)$ fished more than 20 hours per week (Figure $2 b$ ).

Table 4. Estimation of mean individual weekly catch weight, effort, CPUE, and population weekly catch weight and effort.

\begin{tabular}{lllll}
\hline \multirow{2}{*}{ Fishing measurement } & \multicolumn{2}{l}{ Women $(\mathrm{n}=297)$} & Men $(\mathrm{n}=293)$ & \\
& Mean & $(95 \% \mathrm{Cl})$ & Mean & $(95 \% \mathrm{Cl})$ \\
\hline Individual Catch $\left(\mathrm{kg} \bullet\right.$ week $\left.^{-1}\right)$ & 8.69 & $(7.39-10.12)$ & 18.09 & $(15.89-20.56)$ \\
Individual Effort $\left(\mathrm{hrs} \bullet\right.$ week $\left.^{-1}\right)$ & 12.47 & $(10.65-14.34)$ & 29.99 & $(27.59-32.45)$ \\
CPUE $\left(\mathrm{kg} \bullet \mathrm{hr} \mathrm{C}^{-1}\right)$ & 0.97 & $(0.86-1.08)$ & 0.77 & $(0.68-0.88)$ \\
Population Catch $\left(\right.$ tonnes $\bullet$ week $\left.^{-1}\right)$ & 20.29 & $(17.30-23.46)$ & 57.37 & $(50.47-65.04)$ \\
Population Effort $\left(1000 \mathrm{hr}^{\bullet}\right.$ week $\left.^{-1}\right)$ & 28.97 & $(24.88-33.08)$ & 95.17 & $(87.43-103.03)$ \\
\hline
\end{tabular}

Fishers that fish less than 20 hours per week (conservatively defined here as less than full-time fishers) were responsible for just over $31 \%$ of the total weekly catch weight (15\% and $16 \%$ from women and men respectively; Figure 3 ). 
Proportion of Fishers and Catch Mass

by Fishing Effort Categories

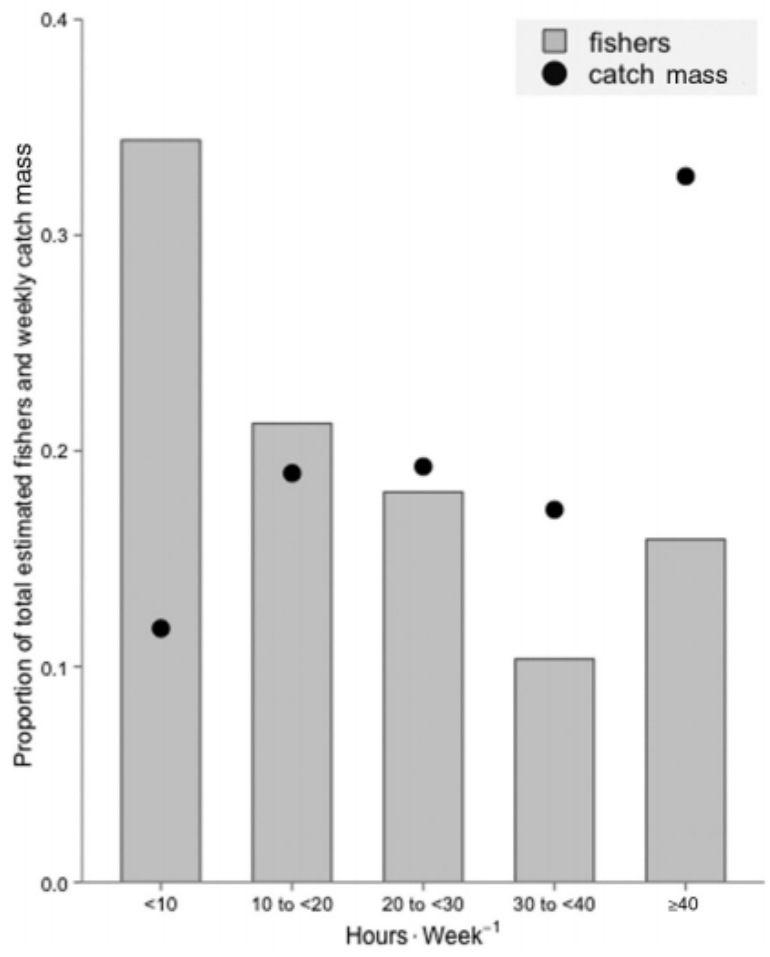

Figure 3. Distribution of the proportional estimated total weekly catch weight by fishing effort, and distribution of the proportion of fishers by fishing effort. 
Total weekly catch mass by Fishing Method

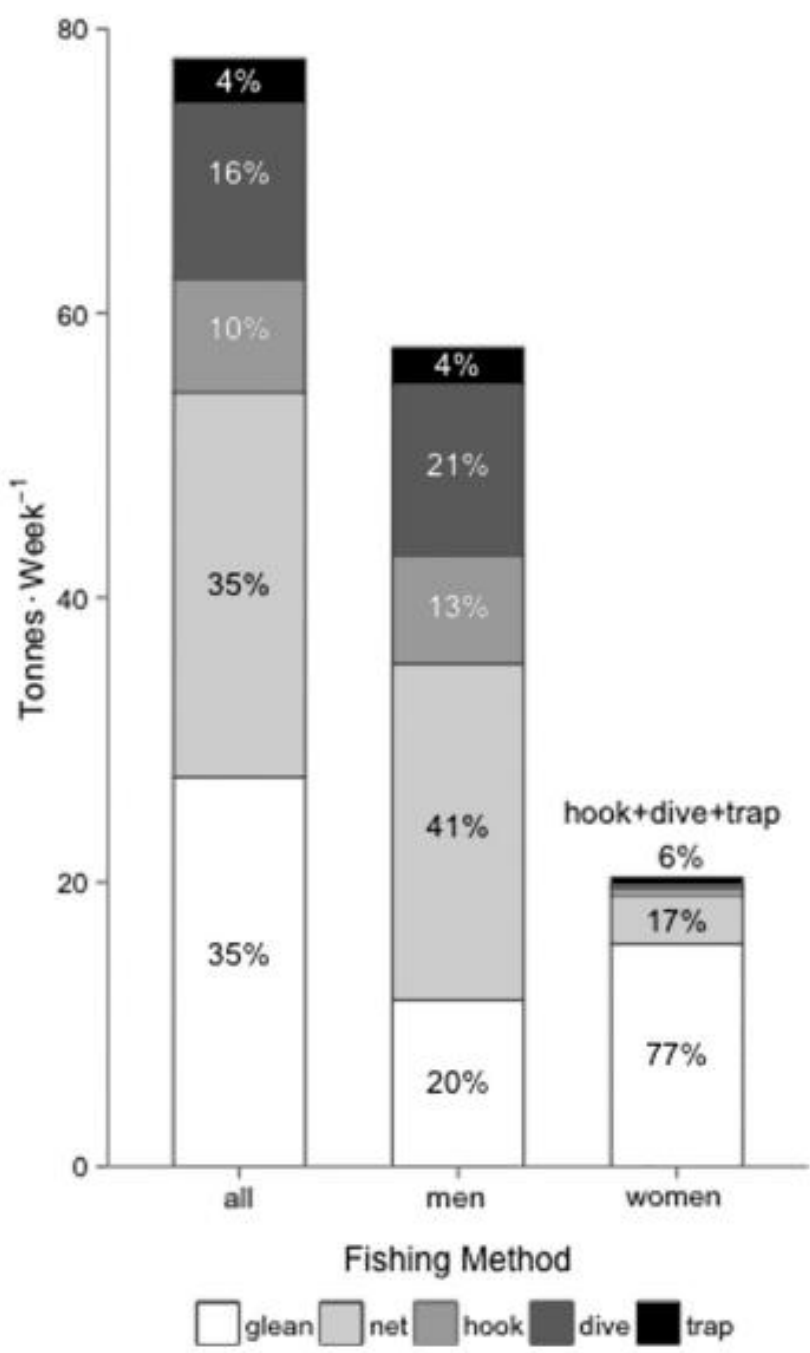

Figure 4. The estimated weekly catch weight of women and men from five different fishing method categories. The proportional contribution of each method type within each fisher category ("all," "men," "women") is added with labels.

Women's catch weight $\left(\mathrm{kg}^{\bullet}\right.$ week $\left.^{-1}\right)$ was mostly from gleaning, while most of men's was from net fishing, although men's catch weight was more evenly distributed amongst the different fishing methods than women's (Figure 4). Together gleaning and net fishing brought in over two-thirds of all catch. 


\section{Animals Targeted by Fishing Methods}

Gleaners extracted mostly gastropods, bivalves, and other sessile invertebrates, while net, hook and dive fishers caught primarily finfish (Figure 5). Fishing traps mostly caught crabs, but were also used to catch finfish. The differences may be due to the different habitats where the fishing occurred. For example, gleaning focused on benthic species available at low tide, while net and hook fishing occurred at a greater range of depths to include swimming species. Similarly, diving occurred at multiple depths but often in coral reef edge areas.

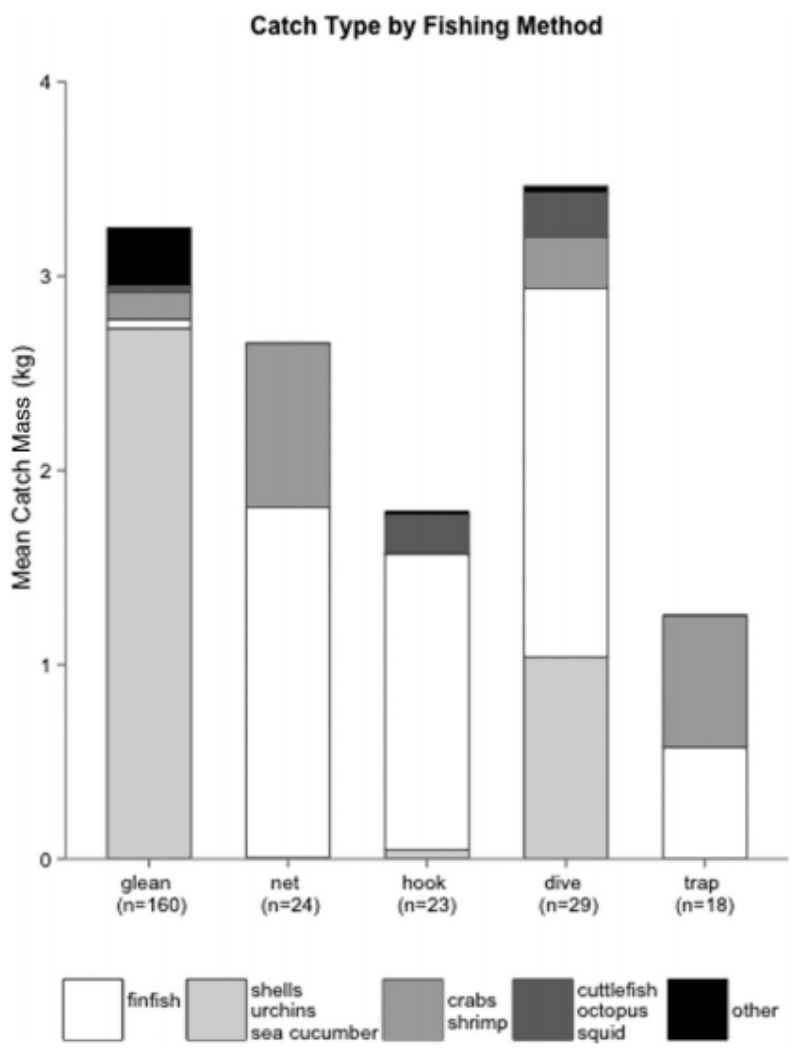

Figure 5. Mean catch by animal category of five fishing methods, directly measured from fishing trips. The "other" category includes all animal and plant types that made up less than $3 \%$ in all fishing methods. It includes seaweeds, jellyfish, and unidentified animals. The sample size of diving catch was low and contained one catch that included a $37 \mathrm{~kg}$ ray. For this reason the mean catch and the dominance of finfish in this category is likely to be an overestimation. 


\section{DISCUSSION}

This study has illustrated distinct and substantial fishing efforts of women, gleaners, and part-time or occasional fishers, emphasizing the importance of including their effort, catch weight, fishing methods, and target species in assessments of small-scale fisheries and ecosystem-based management. This study adds to the growing evidence of women's participation in small-scale fishing, and the heterogeneity of the small-scale fishing strategies in communities (Bliege Bird 2007, Béné et al. 2009, Hauzer et al. 2013). These results suggest that current assessments limited to men, gear-driven methods, full-time fishers, and finfish may produce inadequate representations of smallscale fisheries by underestimating the diversity and totality of human fishing and overlooking important social and ecological interactions. To assess the diversity and totality of small-scale fisheries at a community scale we suggest 1) broader definitions of fishing that take gleaning into account, 2) broader definitions of fishers that take women, part-time fishers, and gleaners into account, and 3) broader definitions of fished species that take benthic macro invertebrates into account. This study, unusual in measuring the number of women fishers and women's contribution to the total catch (among other categories of frequently overlooked fishing participation and practices), helps creates a model for just such changes.

\section{Gender and the Quantification of Small-Scale Fisheries}

Identification and enumeration of fishers is a necessary first step to quantifying fishing effort and catch weight using fisher interviews. To identify fishers at the community scale it is necessary to be aware how being defined as a fisher is mediated by gender roles, definitions of occupation and labour, and definitions of fishing strategies. Women 
may not be identified or self-identify as fishers in contexts where fishing is culturally considered the occupation of men (Yodanis 2000). Part-time or occasional fishers may be less likely to be counted in occupational or labour statistics (Teh and Sumaila 2011), even though part-time labour fisheries is a common occurrence in areas with high occupational diversity (Hill et al. 2012). Gleaners may be similarly overlooked because it is common for only non-gleaning fishing practices to be translated as "fishing" (Lambeth 1999).

Limiting the population of fishers to male, full-time, and non-gleaning fishers underestimated the number of fishers and the totality of fishing catch size at the community scale. In this case study, women, part-time fishers, and gleaners represented $35-55 \%$ of fishers and accounted for between $25-35 \%$ of the total weekly catch weight. Excluding part-time fishers and gleaners disproportionately masked the participation of women (Figure 2), but examining these categories also reveals that considerable portions of men's catch may also be overlooked or underestimated without explicit attention to these categories.

In this case study it is clear that limited definitions of fishers and fishing did not adequately quantify fishers or fishing catch weight at a community scale. These statistics may also have a wider reaching impact if they are used to estimate fishing effort (Teh and Sumaila 2011), indicate fisher density and fishing trends (Christie et al. 2006), or build sustainability models for marine extraction and conservation (Muallil et al. 2012), at regional, national and international scales. Although this study has focused on gender, labour, and fishing methods as key categories that may be overlooked, in other contexts other groups such as migrants, and ethnic, racial, or religious minorities 
should also be considered. (Mills et al. 2011).

\section{Gender and Ecosystem-Based Management}

A gender approach to small-scale fisheries dovetails nicely with the mandate of ecosystem-based management to "scale-up" to include key social and ecological interactions (McLeod et al. 2005, Pomeroy et al. 2010) by broadening the definitions of fisher and fisheries. The inclusion of women fishers allows examination and integration of ecological interactions among fishers and the species they target, as well social interactions at a household and community level. For example women's mangrove fisheries in El Salvador were thought to damage the nursery habitat of species important to men's fisheries (Gammage 2004). The inclusion of women's fishing highlights the ecological interaction between women and men's fisheries and allows for management from an ecosystem scale. Socio-economic interactions between women and men's fisheries also occur at a household and community scale. In the Comoros Islands women and men's fisheries together formed a household subsistence and economic strategy. Within a household women's catch could be used as food thereby freeing up a larger portions of the men's catch to be sold (Hauzer et al. 2013). An example of a community scale economic interaction was found in Mexico where women fished for the bait that men use in their fisheries with the result that any management of men's fishing must absolutely reference women's fishing and vice versa (Savard and Fraga 2005).

In this case study the inclusion of women's fishing broadens the species to be included in ecosystem-scale assessment and management. Women's fishing was dominated by gleaning, a fishing method that targets macro invertebrate species such as bivalves, 
gastropods, sea cucumbers, and urchins (Figure 5). While invertebrates are often recognized as an important marine resource in the Central Philippines, most management tools and plans remain primarily focused on fish species (Armada et al. 2009, Muallil et al. 2012). Such narrowness is misleading, given the role that macro invertebrates play in marine ecosystems as prey (Gell and Roberts 2003), or in maintaining, damaging, or creating key habitat (Pinnegar et al. 2000, Coen et al. 2007). The inclusion of women's fishing allows the delineation of the ecosystem under management to more closely match the community scale at which these resources are being used and managed.

Ecosystem-based management requires the participation of stakeholders in resource management decisions (McLeod et al. 2005) although lack of stakeholder integration has been identified as a key gap between the aspirations and applications of this management approach (Arkema et al. 2006). To this we would add that a clear process to identify stakeholders is similarly lacking, without which minority or marginalized groups may be more likely to be underrepresented, which in turn may have adverse affects on management. For example, a trochus reintroduction project in Tuvalu failed when managers neglected to inform women fishers, who, unaware of the management plan, gleaned the introduced animals (Seniloli et al. 2002). While this study has emphasized the need to include women fishers, an ecosystem-based management approach would also need to include non-fishing participants in the value chain such as processors and marketers that would be affected by management measures. Finally, while the inclusion of women's fisheries in small-scale fisheries assessments aid in the understanding of fisheries and can highlight important interactions, it does not 
guarantee that women and men will be empowered to fully participate in the management of their resources. Hence, the role of gender in community participation in resource management and governance should also be considered (see: Clabots 2012).

\section{Gender and Data Collection}

There are increasing attempts to include women in fisheries and management assessments (e.g. Bacalso et al. 2013), but data collection on women with the goal of gender analysis and integration, often falls short of original intentions (Harrison 1997). This may in part be due to situations where the additional logistical requirements needed to collect accurate gender data (see: Wongbusarakum \& Pomeroy 2000; Quist \& Polotan-De La Cruz 2008; Brugere 2012) are unknown or unimplemented. Future research to expand on the findings of this study should include greater detail on the seasonality of fishing practices, social and economic data on women's and men's participation in small-scale fisheries and management with particular attention to food security, and scale up to national and global assessments by including wider geographic sampling.

The quantitative assessment in this study demonstrates the substantial contribution of women, gleaners, and part-time fishers to the total catch weight and effort, and the greater diversity of fishers and fisheries that may be included using broader definitions. It is of course not possible to collect everything, but this study has demonstrated that there is support for broadening who counts and who gets counted.

\section{ACKNOWLEDGEMENTS}

This is a contribution from Project Seahorse. Bernie Calinajan, Jay Estrella, Venice 
Lazo, and Aileen Montejo conducted all interviews and were invaluable as language and cultural interpreters. Angelie Nellas, Hazel Panes, Mia Apurado, and the Project Seahorse Foundation staff provided logistical support and research feedback. Pierre Kleiber, Gabriel Amos, Jennifer Selgrath, and Ting-Chun Kuo generously gave advice on the analysis and structure of the manuscript. D.K. received funding for this project from the World Wildlife Fund, the University of British Columbia Liu Institute, and the International Federation of University Women. This project also benefited from support by Guylian Chocolates Belgium and an anonymous donor through their partnerships for marine conservation with Project Seahorse.

\section{BIBLIOGRAPHY}

Adeokun, O.A., and Adereti, F.O. 2003. Agricultural extension and fisheries development: training for women in fish industry in Lagos - State, Nigeria. J. Agric. Soc. Res. 3: 64-76.

Agarwal, B. 2009. Rule making in community forestry institutions: The difference women make. Ecol. Econ. 68: 2296-2308.

Allison, E.H., and Ellis, F. 2001. The livelihoods approach and management of small-scale fisheries. Mar. Policy 25: 377-388.

Andrew, N.L., Béné, C., Hall, S.J., Allison, E.H., Heck, S., and Ratner, B.D. 2007. Diagnosis and management of small-scale fisheries in developing countries. Fish Fish. 8: 227-240.

Arkema, K.K., Abramson, S.C., and Dewsbury, B.M. 2006. Marine ecosystem-based management: from characterization to implementation. Front. Ecol. Environ. 4: 525-532.

Armada, N.B., White, A.T., and Christie, P. 2009. Managing Fisheries Resources in Danajon Bank, Bohol, Philippines: An Ecosystem-Based Approach. Coast. Manag. 37: 308-330.

Bacalso, R.T.M., Juario, J. V, and Armada, N.B. 2013. Fishers' choice of alternative management scenarios: A case study in the Danajon Bank, Central Philippines. Ocean Coast. Manag. 84: 40-53.

Béné, C., Macfayden, G., and Allison, E.H. 2007. Increasing the contribution of small-scale fisheries to poverty alleviation and food security. FAO Fish. Tech. Pap. 481: 125. Rome, Italy. 
Béné, C., Steel, E., Luadia, B., and Gordon, A. 2009. Fish as the "bank in the water" - Evidence from chronic-poor communities in Congo. Food Policy 34: 108-118.

Bliege Bird, R.L. 2007. Fishing and the Sexual Division of Labor among the Meriam. Am. Anthropol. 109: 442-451.

Brugere, C. 2012. Mainstreaming gender in the BOBLME Project: Gender audit and recommended actions for mainstreaming a gender perspective in the BOBLME project and its Strategic Action Programme (SAP).

Carpenter, K.E., and Springer, V.G. 2005. The center of the center of marine shore fish biodiversity: the Philippine Islands. Environ. Biol. Fishes 72: 467-480.

Chao, A., Jost, L., Chiang, S.C., Jiang, Y.-H., and Chazdon, R.L. 2008. A two-stage probabilistic approach to multiple-community similarity indices. Biometrics 64: 1178-86.

Chapman, M.D. 1987. Women’s fishing in Oceania. Hum. Ecol. 15: 267-288.

Charney, N., and Record, S. 2013. Jost Diversity Measures for Community Data, Package "vegetarian." Amherst.

Christie, P., Armada, N.B., White, A.T., Gulayan, A.M., and de Dios, H.H.Y. 2006. Coastal Environmental and Fisheries Profile of Danajon Bank, Bohol, Philippines. In Hermes. Fisheries Improved for Sustainable Harvest (FISH) Project, Cebu City, Philippines.

Clabots, B. 2012. For a better tomorrow. Yemaya 41: 8-9.

Coen, L.D., Brumbaugh, R.D., Bushek, D., Grizzle, R., Luckenbach, M.W., Posey, M.H., Powers, S.P., and Tolley, S.G. 2007. Ecosystem services related to oyster restoration. Mar. Ecol. Prog. Ser. 341: 303-307.

FAO, and WorldFish Centre. 2008. Small-scale capture fisheries: A global overview with emphasis on developing countries. A preliminary report of the Big Numbers Project. FAO, Rome, Italy.

Gammage, S. 2004. The tattered net of statistics. In Gender Agenda - Women in Fisheries: a Collection of Articles from SAMUDRA Report. Edited by K.G. Kumar. International Collective in Support of Fishworkers (ICSF), India. pp. 36-40.

Gell, F., and Roberts, C.M. 2003. Benefits beyond boundaries: the fishery effects of marine reserves. Trends Ecol. Evol. 18: 448-455.

Gelman, A., and Hill, J. 2009. Data analysis using regression and multilevel/hierarchical models. Cambridge University Press, Cambridge. 
Harrison, E. 1997. Fish, Feminists and the FAO: Translating "Gender" through differing institution in the development process. In Getting Institutions Right for Women in Development. Edited by A.M. Goetz. Zed Books, London \& New York. pp. 61-76.

Hauzer, M., Dearden, P., and Murray, G. 2013. The fisherwomen of Ngazidja island, Comoros: Fisheries livelihoods, impacts, and implications for management. Fish. Res. 140: 28-35.

Hill, N.A.O., Rowcilffe, J.M., Koldewey, H.J., and Milner-Gulland, E.J. 2012. The Interaction between Seaweed Farming as an Alternative Occupation and Fisher Numbers in the Central Philippines. Conserv. Biol. 26: 324-334.

Illo, J.F.I., and Polo, J.B. 1990. Fishers, traders, farmers, wives: the life stories of ten women in a fishing village. Institute of Philippine Culture, Ateneo de Manila University, Manila, Philippines.

Lambeth, L. 1999. What's a "fisher"? Yemaya 2: 9.

Magalhães, A., da Costa, R.M., da Silva, R., and Pereira, L.C.C. 2007. The role of women in the mangrove crab (Ucides cordatus, Ocypodidae) production process in North Brazil (Amazon region, Pará). Ecol. Econ. 61: 559-565.

Matthews, E. 2002. Integrating women's subsistence fishing into Pacific fisheries and conservation programmes. SPC Women Fish. Inf. Bull. 11: 13-14.

McCluskey, S.M., and Lewison, R.L. 2008. Quantifying fishing effort: a synthesis of current methods and their applications. Fish Fish. 9: 188-200.

McLeod, K., Lubchenco, J., Palumbi, S.R., and Rosenberg, A.A. 2005. Scientific Consensus Statement on Marine Ecosystem-Based Management. Signed by 221 academic scientists and policy experts with relevant expertise and published by the Communication Partnership for Science and the Sea at http://compassonline.org/?q=EBM.

Medard, M. 2012. Relations between People, Relations about Things: Gendered Investment and the Case of the Lake Victoria Fishery, Tanzania. Signs (Chic). 37: 555-566.

Metuzals, K., Bairds, R., Pitcher, T.J., Sumaila, U.R., and Ganapathiraju, P. 2010. One Fish, Two Fish, IUU, and No Fish: Unreported Fishing Worldwide. In Handbook of Marine Fisheries Conservation and Management. Edited by R.Q. Grafton, R. Hilborn, D. Squires, M. Tait, and M.J. Williams. Oxford University Press, Oxford. pp. 165-181.

Mills, D.J., Westlund, L.L., de Graaf, G., Kura, Y., Willmann, R., and Kelleher, K. 2011. Underreported and Undervalued: Small-scale Fisheries in the Developing World. In Small-scale Fisheries Management: Frameworks and Approaches for the Developing World. Edited by R.S. Pomeroy and N.L. Andrew. CABI Publishing, Oxfordshire, UK. pp. 1-15. 
Muallil, R.N., Cabral, R.B., Mamauag, S.S., and Aliño, P.M. 2012. Status, trend and sustainability of small-scale fisheries in the Philippines. In 12th International Coral Reef Symposium. Cairns. pp. 9-13.

Neis, B., Schneider, D.C., Felt, L., Haedrich, R.L., Fischer, J., and Hutchings, J.A. 1999. Fisheries assessment: What can be learned from interviewing resource users? Can. J. Fish. Aquat. Sci. 56: 1949-1963.

O’Donnell, K.P., Pajaro, M.G., and Vincent, A.C.J. 2010. How does the accuracy of fisher knowledge affect seahorse conservation status? Anim. Conserv. 13: 526-523.

Overå, R. 1993. Wives and Traders: Women's Careers in Ghanaian Canoe Fisheries. MAST. Marit. Anthropol. Stud. 6: 110-135.

Pinnegar, J.K., Polunin, N.V.C., Francour, P., Badalamenti, F., Chemello, R., Harmelin-Vivien, M.L., Hereu, B., Milazzo, M., Zabala, M., D’Anna, G., and Pipitone, C. 2000. Trophic cascades in benthic marine ecosystems: lessons for fisheries and protected-area management. Environ. Conserv. 27: 179-200.

Pomeroy, R.S., Garces, L., Pido, M., and Silvestre, G. 2010. Ecosystem-based fisheries management in small-scale tropical marine fisheries: Emerging models of governance arrangements in the Philippines. Mar. Policy 34: 298-308.

Quinn, N.J., and Davis, M.T. 1997. The productivity and public health considerations of the urban women's daytime subsistence fishery off Suva Peninsula, Fiji. South Pacific J. Nat. Sci. 15: 63-92.

Quist, C., and Polotan-De La Cruz, L. 2008. Integrating a gender perspective in CBCRM approaches: a review of experiences and best practices of Oxfam Novib partners in Southeast Asia and other efforts from world wide. In Gender and Development.

R Development Core Team. 2011. R: A language and environment for statistical computing. R Foundation for Statistical Computing, Vienna, Austria.

Resurreccion, B.P., and Elmhirst, R. 2008. Gender and Natural Resource Management: livelihoods, mobility, and interventions. Earthscan, London.

Savard, K., and Fraga, J. 2005. A Bottom-Up Approach to the Creation of a Marine Protected Area in San Felipe, Mexico: Gender Relations, Governance Mechanisms and Globalization. In Changing Tides: Gender, Fisheries and Globalization. Edited by B. Neis, M. Binkley, S. Gerrard, and C. Maneschy. Fernwood Publishing, Halifax, Nova Scotia. pp. 169-181.

Seniloli, M., Taylor, L., and Fulivai, S. 2002. Gender issues in environmental sustainability and poverty reduction in the community: social and community issues. Dev. Bull. 58: 96-98. 
Siar, S. V. 2003. Knowledge, gender, and resources in small-scale fishing: the case of Honda Bay, Palawan, Philippines. Environ. Manage. 31: 569-80.

Teh, L.C.L., and Sumaila, U.R. 2013. Contribution of marine fisheries to worldwide employment. Fish Fish. 14: 77-88.

Tindall, C., and Holvoet, K. 2008. From the Lake to the Plate: Assessing gender vulnerabilities throughout the fisheries chain. Development 51: 205-211.

United Nations. 2006. The world's women 2005: Progress in Statistics. In Development. New York.

Upadhyay, B. 2005. Women and natural resource management: Illustrations from India and Nepal. Nat. Resour. Forum 29: 224-232.

Vernooy, R. (Editor). 2006. Social and Gender Analysis in Natural Resource Management: Learning Studies and Lessons from Asia. Sage Publications, New Delhi.

Walker, B.L.E., and Robinson, M.A. 2009. Economic development, marine protected areas and gendered access to fishing resources in a Polynesian lagoon. Gender, Place Cult. 16: 467484.

Weeratunge, N., Snyder, K.A., and Choo, P.S. 2010. Gleaner, fisher, trader, processor: understanding gendered employment in fisheries and aquaculture. Fish Fish. 11: 405-420.

Wongbusarakum, S., and Pomeroy, R.S. 2000. SEM-Pasifika: Socioeconomic Monitoring Guidelines for Coastal Managers in Pacific Island Countries. SPREP.

Yap, W.G. 1999. Rural Aquaculture in the Philippines. Bangkok, Thailand.

Yodanis, C.L. 2000. Constructing Gender and Occupational Segregation: A Study of Women and Work in Fishing Communities. Qual. Sociol. 23: 267-290.

Zeller, D., Booth, S., Davis, G., and Pauly, D. 2007a. Re-estimation of small-scale fishery catches for U.S. flag-associated island areas in the western Pacific: the last 50 years. Fish. Bull. 105: 266-277.

Zeller, D., Booth, S., and Pauly, D. 2007b. Fisheries contribution to the Gross Domestic Product: underestimating small-scale fisheries in the Pacific. Mar. Resour. Econ. 21: 355-374. 